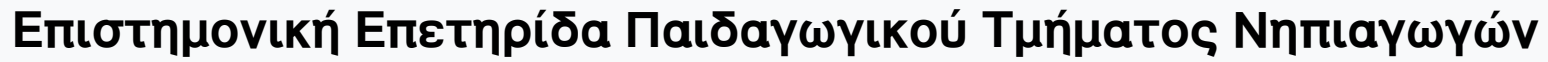

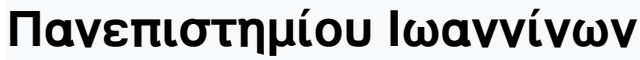

\author{
Tóp. 9, Ap. 1 (2016)
}

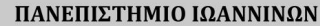

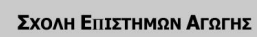

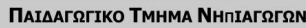

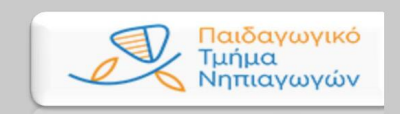

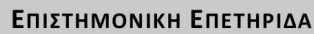

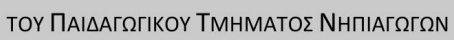

JOURNAL OF RESEARCH IN EDUCATION AND TRAINING

DEPARTMENT OF EARLY CHILDHOOD EDUCATION

TOMOE $9-$ VOL 9

APIOMOE 1- NO 1

2016
Physical education in early education: An intervention program for reducing aggressive and social insecure behavior

Katerina Mouratidou

doi: $\underline{10.12681 / j r e t .8731}$

Copyright (C) 2016, Katerina Mouratidou

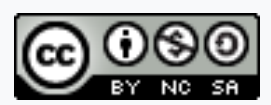

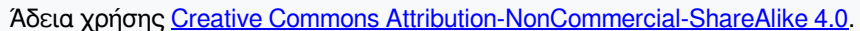

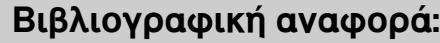

Mouratidou, K. (2016). Physical education in early education: An intervention program for reducing aggressive and social

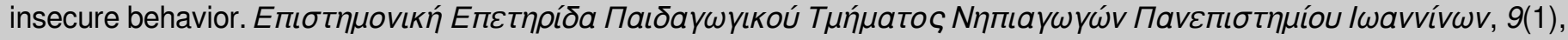
208-229. https://doi.org/10.12681/jret.8731 


\title{
Physical education in early education: An intervention program for reducing aggressive and social insecure behavior
}

\author{
Mouratidou Katerina \\ School of Physical Education and Sport Science at Serres, Aristotle University of \\ Thessaloniki
}

\begin{abstract}
The present study aimed to examine the effect of a physical education program on the reduction of aggressive and social insecure behavior of young children. The sample comprised of 194 children, aged 4-5 years. The experimental group consisted of 99 children, while the rest 95 children formed the control group. The experimental group participated in an 8-week physical education program, based on physical activities and kinetic theatrical playing, while the control group was engaged in free-play activities during the same period. All participants completed the Checklist of Aggressive Behavior (CAB) (Petermann \& Petermann, 2001) and the Checklist of Social Insecure Behavior (CSIB) (Petermann \& Petermann, 2003). The results revealed that the experimental group exhibited statistically lower aggressive and social insecure behaviors after the intervention compared to the control group. These findings indicate that an appropriate design of physical education could support social development in early childhood.
\end{abstract}

Key-words: physical education, pre-school children, social behavior, aggression

Correspondent Author: Mouratidou Katerina

Department: School of Physical Education and Sport Science at Serres University:

Aristotle University of Thessaloniki

e-mail: katemou@phed-sr.auth.gr

e-publisher: National Documentation Centre, National Hellenic Research Foundation

URL: http://ejournals.epublishing.ekt.gr/index.php/jret/index 


\section{Introduction}

Schools provide a sound environment for supporting children's socialization. As past research has shown, the interaction among schoolmates strengthens children's social, emotional and behavioral adjustment (Altermatt,_2011; Chung-Hall \& Chen, 2010; Hernández et al., 2016; Sandstrom, Cillessen, \& Eisenhower, 2003; Zhang, Zhao, Liang, Li, Chen, \& Chen, 2015; Zupančiča \& Kavčiča, 2011). In general, when a child faces peer acceptance and also interacts positively with her/his classmates, as a result s/he displays better academic achievement, skills and engagement. It can also be pointed out that the child presents even higher social competence and psychological adjustment (Altermatt, 2011; Chung-Hall \& Chen, 2010; Hernández et al., 2016; Rossem, Vermande, Völker, \& Baerveldt, 2015; Zhang et al., 2015). Additionally, as previous studies revealed, children at risk for peer rejection/victimization are those who have poor social skills and are vulnerable to internalization (i.e., children who are weak and display internalizing behaviors) and those whose peer status is low (Boivin, Hymel, \& Bukowski, 1995; Dodge et al., 2003; Hodges \& Perr, 1999). It' s worth to be noticed that - according to group socialization theory (Harris, 1995) - peers affect significantly a child's social development, since peer groups are a decisive context for individual development (Rubin, Bukowski, \& Parker, 2006).

Furthermore, a well-documented finding in research literature is that social competence is one of the most significant predictors of pupils' social adjustment both cross-sectionally and prospectively (Parker \& Asher, 1987; Rossem et al., 2015; Sandstrom et al., 2003; Stan, 2013). More specifically, social skills play a key-role for a pre-schooler's school readiness and adjustment (Denham, 2006; Rimm-Kaufman, Pianta, \& Cox, 2000), so that McClelland and colleges (McClelland \& Morrison, 2003; McClelland, Morrison, \& Holmes, 2000) claimed that there are specific social behaviors (such as independence, responsibility, self-regulation, and cooperation), which are related to children's early school adjustment and academic achievement. In addition, it seems that a social responsible behavior affects positively a classroom's climate, since it creates a conducive environment for learning and cognitive development (Greenberg et al., 2003; Rossem et al., 2015; Wentzel, 1991). 
Nonetheless, the term social competence is defined as a multifaceted developmental construct, and, as such, can hardly be confined into a generally accepted definition. This difficulty could be attributed also to cultural differences, since previous findings (Chen et al., 2004) showed that Chinese, Brazilian, Canadian and Italian children perceive differently the term social competence; however the majority of the research and academic community claims that social competence is synonymous - among others - with 'effectiveness in social interaction' (Chen et al., 2004; Rose-Krasnor, 1997). This would in turn mean that socially efficient behavior is a person's qualitative interaction with her/his social environment (see also Howes, 1987; Yeates \& Selman, 1989). Therefore, a child could be characterized as social competent when $\mathrm{s} /$ he is able to interact efficiently with her/his peers and/or adults and enjoys popularity; on the contrary, a child who faces problems in interacting with peers will be more likely to manifest different maladaptive behaviors, including - among others aggressive acts or isolation and social fear (see also Rose-Krasnor, 1997), since such behaviors could be considered also as an indicator of less social competence.

According to Petermann and Petermann (2003), a socially isolated child who displays social anxiety, excessive shyness, withdrawal and social avoidance, is characterized as a socially insecure child. More specifically, socially insecure child is a girl/boy who: a) refuses to be separated from one specific adult, to get out of the house, and to correspond to any social invitation (which is related to separation anxiety), b) displays anxiety towards less familiar persons, and anxiety for evaluation with regard to social circumstances, where performance is dominated (this is social anxiety or phobia), and c) worries about her/his skills, success and competence on handling problems in different circumstances of daily life (the so called generalized anxiety disorder) (Mouratidou, Barkoukis, Zahariadis, \& Arampatzi, 2007a). Results of relevant studies showed that, an insecure child acts in a more hostile and antisocial manner (Erickson, Sroufe, \& Egeland, 1985) and is more dependent upon her/his peers (Turner, 1991) than a secure one.

On the other hand, Citrome and Volanka defined (2001) aggressive behavior as the behavior that intends to induce painful stimulants to other people or to perform a catastrophic behavior to objects. Aggressiveness could be externalized verbally (wordy attack) or non-verbally (shooting objectives) and is not always directed 
against another person (i.e. child or adult; external world), since sometimes could be transformed to indifference or directed against the person itself (Papadopoulos, 1994). However, it should be mentioned here that verbal and nonverbal aggressions are the two main subscales, within which are assessed the overt/covert aggression, the victimization, and the participation degree to the aggressive act (i.e. aggression is experienced passively or actively provoked).

On the basis of the above evidence, then, it could be argued that aggressive and social insecure behaviors represent two rather crucial aspects of children's social competence. In short, two basic elements for the definition of a child's social competence are: a) whether s/he acts aggressively and/or expresses social insecure behavior, and b) whether s/he externalizes socially competent behaviors such as, participating in groups or team work activities, expressing emotions, and playing with classmates. An aggressive behavior or a social insecure behavior are not in favor of fostering the positive coexistence and communication among students, but unfavorably is dysfunctional for the process of socialization.

Previous studies, which were conducted in order to examine pupils' social competence revealed that: (a) In kindergarten, overt aggression (for boys), and sharing and engaging in sneaky behavior (for girls) mediate the relation between preschool problem behaviors and peer status; this means that specific behaviors displayed in the peer group account for the relation between early problem behavior and peer status (Keane \& Calkins, 2004), (b) violence exposure is closely associated with externalizing behavior, such as willingness to use physical aggression, as well as with internalizing symptoms such as depression, and anxiety (Schwab-Stone, Chen, Greenberger, Silver, Lichtman, \& Voyce, 1999), (c) there is a moderate to strong association between fire setting and both shyness and aggression, and feeling highly rejected by peers (Chen, Arria, \& Anthony, 2003), (d) relational aggression is significantly related to social-psychological maladjustment (e.g., peer rejection) for both boys and girls (Crick, Casas, \& Mosher, 1997), (f) overt aggression is positively correlated with friendship conflict (Sebanc, 2003), and (g) aggressive children perceive less control over social success than withdrawn children, and withdrawn children rate seeking peaceful solutions and relationships maintenance goals higher than aggressive children (Wichmann, Coplan, \& Daniels, 2004). 
Moreover, the empirical findings concerning aggression and/or socially insecure behavior in early childhood showed that (a) the relation between maladaptive emotion regulation and aggression is direct and not mediated by social information processing biases (i.e., aggressive response generation, aggressive response evaluation and decision) (Helmsen, Koglin, \& Petermann, 2012) (b) change in rates of aggression is non-linear (i.e., increasing then decreasing over the year) (Roseth, Pellegrini, Bohn, Van Ryzin, \& Vance, 2007), (c) physical and verbal forms of aggression are associated with distinct longitudinal trajectories; in turn these trajectories are related to rates of affiliation and visual regard, while social dominance accounts for significant variation in these patterns (Roseth et al., 2007), (d) children with higher stress are more likely to demonstrate low social competence when they are in class with other children with less optimal social competencies (Brophy-Herb, Lee, Nievar, Stollak, 2007), (e) appropriate intervention programs could increase children's social competence, reduce their violence, promote their emotional literacy and their social problem-solving skills, and help them externalize their problems (Howell, Miller, Lilly, \& Graham-Bermann, 2013; Ştefan \& Miclea, 2013) and (f) children's aggressive behavior is associated with early-emerging, sustained difficulties including low peer acceptance and conflictual teacher-child relationships; more specifically, aggressive/withdrawn children are consistently more lonely, dissatisfied, friendless, disliked, victimized, and likely to have maladaptive teacher-child relationships (Ladd \& Burgess, 1999).

In light of these findings, students' socialization is considered as an integral part of education and is included in the list of educational goals of curricula designing and development (IPC, 2005; IPEPTH, 2008; NASPE, 2004). More particularly for the early childhood education it seems that the promotion of children's social development is one of its main focus (Gregoriadis, Grammatikopoulos, \& Zachopoulou, 2013; Serpell \& Mashburn, 2012).

Physical education (PE) due to its nature could be seen as an appropriate environment for supporting students' social developing: During PE children have the possibility on one hand to interact intensively with peers and on the other to face socio-moral conflicts, which in turn are important elements for a child's socio-moral enhancement (McLaughlin \& Byers, 2001; Telama, 1999). PE offers numerous opportunities for 
effective interactions among peers, and establishing attitudes and affections towards other people; children not only interact with each other due to the nature of physical education (while in other school subjects that occur in classroom, the interaction among students is limited), but they have in most cases to coexist with respect to each other, to cooperate, and to help each other (Mouratidou, 2010). Research has placed focus on this topic and has revealed that a) PE contributes to a great extent in fostering children's socialization/social skills (Bailey et al., 2009; Quay \& Peters, 2008), b) physical activity and socialization behaviors are highly embedded and cooccur frequently in the daily lives of typical developing toddlers (Logan, Schreiber, Ragonesi, Pritchard, George, \& Galloway, 2014), and c) appropriate intervention programs during physical education classes affect positively students' socio-moral development (Gibbons \& Ebbeck, 1997; Gibbons, Ebbeck, \& Weiss, 1995; Miller, Bredemeier, \& Shields, 1997; Mouratidou, Goutza, \& Chatzopoulos, 2007b; Pavlidou, Arvanitidou, \& Chatzigeorgiadou, 2012; Tsangaridou, Zachopoulou, Liukkonen, Grasten, \& Kokkonen, 2014).

\section{Aims and hypotheses of the study}

From the literature reviewed so far it seems that although there is substantial evidence concerning the examination of aggressiveness and other aspects of students' social development, more research is needed in order to establish and adapt an appropriate physical education (PE) program aiming to strengthen such development, especially in pre-school age. Hence, the purpose of the present study was to examine the effectiveness of a PE intervention program (based on physical activities and kinetic theatrical playing) for reducing young children's aggressive and social insecure behavior. The basic hypothesis of the study was that the PE program will positively affect the children's aggressive and/or social insecure behavior. 


\section{Method}

\section{Participants}

The sample consisted of 194 pre-school students (106 males, 88 females), ranging in age from 4 to 5 years old $\left(\mathrm{M}_{\mathrm{age}}=4.57\right.$ years, $\left.\mathrm{SD}=0.50\right)$, who represented the overall population of five randomly selected pre-school centers (10 intact pre-school classrooms) in North Greece. At the beginning of the study, and in order to recognize the effects of the intervention program five classrooms were randomly chosen to constitute the experimental group ( $\mathrm{N}=99,52$ boys and 47 girls), while the other five classrooms formed the control group ( $\mathrm{N}=95,54$ boys and 41 girls). All participants attended preschool daily, five days a week, in groups of about 20 children, with ten preschool teachers.

\section{Design of intervention and procedure}

In the present study, the intervention program was based on and utilized physical activities, and kinetic theatrical playing. The intervention lasted eight weeks. Children in experimental group attended physical education classes three times per week for a total of 24 lessons. The subject matter of the PE lessons during this specific time duration included physical activities without elements of competition and kinetic theatrical playing. More specifically, all physical activities (motor games, exercises etc.) introduced during the program were concentrated on enhancing basic sensualmotor abilities (such as self-concept, orientation, balance, etc.) (for more information about these activities see also Zachopoulou \& Trevlas, 2007) and were taught through the reciprocal teaching style. Moreover, day-lessons concerned the kinetic theatrical playing were based on Schmolke's model of body theater (Schmolke, 1976; Rosenberg, 1990), considered activities such as imitation of diverse characters, original use of body parts and pantomime and aimed to promoting preschoolers' selfexpression, creativity and non verbal communication through the guided discovery teaching style.

The intervention program was taught by five regular pre-school educators, who were earlier introduced to the specific framework of the program and had received the respective 24 lessons prepared by the researcher. The participants of the control group 
followed the regular curriculum for the specific educational time period that included diverse activities (such as pedagogical games, kids arts and crafts activities), also with their regular pre-school educators, but they didn't participate in some kind of physical education during that period.

One week before the start and right after the end of the program (pre- and post-test respectively) all the educators completed the study's questionnaire separately for each of their student, apart from teaching hours; earlier, the questionnaire was approved by the Pedagogical Institute, which also granted permission to conduct research within the schools. Moreover, the parents of the children were informed about the study and parental informed consent was granted. Both the educators as well as the parents were ensured that the participation was voluntary and that the responses would remain confidential.

\section{Measures}

The questionnaire of the present study consisted of two checklists, which concerned students' aspects of social competence (i.e. aggression and social insecurity): Checklist of Social Insecure Behavior - CSIB (Peterman \& Peterman, 2003; Mouratidou et al., 2007a for Greek version) and Checklist of Aggressive Behavior CAB (Peterman \& Peterman, 2001; Mouratidou et al., 2007a for Greek version). The completion aimed to assess the effectivity of the intervention program. Specifically:

In order to assess students' aggressive behavior $\mathrm{CAB}$ was used. The $\mathrm{CAB}$ comprised of 14 items which are classified in 3 factors: a) verbal behavior ( 5 items; example item: "Child screams, scolds, and insults adults and children"), b) non-verbal behavior (5 items; example item: "Child eats his nails, pulls his hair, hits his head") and c) positive behavior ( 4 items; example item: "Child is characterized by readiness of cooperation and compromise").

CSIB was used in the present study to assess students' social insecure behavior. CSIB consists of 16 items, which are classified in five factors: a) Verbal reactions (3 items; example item: "Child cannot complete a word or a sentence with coherence"), b) body language (4 items; example item: "Child's hands shake, eats his/her pencil and/or his/her nails, plays with his/her hands nervously), c) activities (3 items; example item: 
"Child quits when he/she fails in a game or when he/she does not correspond to a social task"), d) social contact (4 items; example item: "S/he does not participate in any group of playing children, refuses to correspond to a social invitation") and e) self-defence ( 2 items; example item: "S/he can make logical demands, he/she can express his/her view or use critic").

In both checklists, responses are given in a five-point Likert scale, ranging from 'never appears' (1) to 'always appears' (5). Furthermore, in CAB the items assessing positive behavior and in CSIB the self-defence items are reversed. For both checklists a composite score of the teachers' evaluation is obtained to reveal the children's behavior. A low total score indicates high positive behavior, while a high one implies high negative social behavior (table 1 represents the interpretation of the aggressive and/or social insecure behavior, according to the total score). In addition, both checklists were earlier validated for Greek population and showed appropriate indexes (see Mouratidou et al. 2007a); they were chosen since they are appropriate for clinical and/or educational assessments in children (Petermann \& Petermann 2001, 2003).

\section{Table 1}

Assessment of "Checklist of Aggressive Behavior" (CAB), and "Checklist of Social Insecure Behavior" (CSIB).

\begin{tabular}{ll}
\hline CAB / CSIB & Assessment of behavior \\
\hline $14-21$ & No problematical behavior. Seldom apparent \\
$22-35$ & Most times no problematical behavior. Sometimes apparent \\
$36-49$ & Behavior that appears sometimes or/and regularly \\
$50-63$ & Particularly apparent behavior. It is observed in many circumstances \\
$64-70$ & Excessively apparent behavior \\
\hline
\end{tabular}

CAB and CSIB were completed by the teachers separately for each student, apart from teaching hours. They had been given instructions earlier for the completion for both checklists by the investigator. No difficulties emerged as far as answering the items of the questionnaire. Finally, in order the measures of the pre-test to be corresponded with the respective measures of the post-test, and students' anonymity to be ensured, a code was utilized instead of their names (the initial of the first and last name, the class grade and the initial of teacher's last name). 


\section{Data Analysis}

At the beginning and at the end of the intervention and in order to determine whether there were any differences in the participants' aspects of social competence, four Ttest for independent samples were conducted. The effects of the program on children's social insecure and aggressive behavior were examined at the end of the intervention with two 2 (within-subjects factor time: pre-test and post-test) $\mathrm{X} 2$ (between-subjects factor group: intervention group, and control group) repeated measures ANOVAs. The statistical significance was set at the .05 level. 


\section{Results}

\section{Descriptive statistics}

Means (M) and standard deviations (SD) for all variables apart for each group on preand post-test are listed in Table 2. As it can be seen, the aggressive and social insecure behaviors displayed by the children were in most cases not problematical. Particularly, in pre-test the mean scores for aggressive and social insecure behavior were $\mathrm{M}=28.87, \mathrm{SD}=6.86$ and $\mathrm{M}=28.80, \mathrm{SD}=7.95$ respectively. Similarly, low mean scores were found in post-test for aggressive behavior $\mathrm{M}=25.46, \mathrm{SD}=9.55$ and for social insecure behavior $\mathrm{M}=23.66, \mathrm{SD}=8.31$.

Table 2

Means (M) and standard deviations of the variables for each group, before and after the intervention program

\begin{tabular}{|c|c|c|c|c|c|c|c|c|c|c|c|c|}
\hline & \multicolumn{6}{|c|}{ Pretest } & \multicolumn{6}{|c|}{ Posttest } \\
\hline & \multicolumn{2}{|c|}{$\begin{array}{l}\text { Experimental } \\
\text { Group }\end{array}$} & \multicolumn{2}{|c|}{ Control group } & \multicolumn{2}{|c|}{ Total } & \multicolumn{2}{|c|}{$\begin{array}{l}\text { Experimental } \\
\text { Group }\end{array}$} & \multicolumn{2}{|c|}{ Control group } & \multicolumn{2}{|c|}{ Total } \\
\hline & $\mathbf{M}$ & SD & $\mathbf{M}$ & SD & $\mathbf{M}$ & SD & M & SD & $\mathbf{M}$ & SD & $\mathbf{M}$ & SD \\
\hline $\begin{array}{l}\text { Social } \\
\text { insecure } \\
\text { behavior }\end{array}$ & 27.64 & 7.55 & 29.76 & 8.18 & 28.80 & 7.95 & $\begin{array}{r}19.4 \\
5\end{array}$ & $\begin{array}{r}4.7 \\
0\end{array}$ & $\begin{array}{r}27.1 \\
6\end{array}$ & 9.03 & $\begin{array}{r}23.6 \\
6\end{array}$ & 8.31 \\
\hline Males & $\begin{array}{r}27.5 \\
8 \\
\end{array}$ & $\begin{array}{r}6.8 \\
2 \\
\end{array}$ & $\begin{array}{r}29.8 \\
5 \\
\end{array}$ & $\begin{array}{r}8.2 \\
1 \\
\end{array}$ & $\begin{array}{r}28.8 \\
7 \\
\end{array}$ & $\begin{array}{r}7.6 \\
9 \\
\end{array}$ & 18.90 & $\begin{array}{r}3.5 \\
9 \\
\end{array}$ & $\begin{array}{r}27.0 \\
0 \\
\end{array}$ & 7.18 & $\begin{array}{r}23.5 \\
0\end{array}$ & 7.12 \\
\hline Females & $\begin{array}{r}27.7 \\
0 \\
\end{array}$ & $\begin{array}{r}8.2 \\
0 \\
\end{array}$ & $\begin{array}{r}29.6 \\
7 \\
\end{array}$ & $\begin{array}{r}8.2 \\
2 \\
\end{array}$ & $\begin{array}{r}28.7 \\
3 \\
\end{array}$ & $\begin{array}{r}8.2 \\
3 \\
\end{array}$ & 19.93 & $\begin{array}{r}5.4 \\
9 \\
\end{array}$ & $\begin{array}{r}27.3 \\
2 \\
\end{array}$ & $\begin{array}{r}10.6 \\
9\end{array}$ & $\begin{array}{r}23.8 \\
1 \\
\end{array}$ & 9.35 \\
\hline $\begin{array}{l}\text { Aggressi } \\
\text { ve } \\
\text { behavior }\end{array}$ & 28.10 & 6.75 & 29.51 & 6.9 & 28.87 & 6.86 & 21.63 & $\begin{array}{r}4.9 \\
6\end{array}$ & $\begin{array}{r}28.6 \\
5\end{array}$ & $\begin{array}{r}11.1 \\
7\end{array}$ & $\begin{array}{r}25.4 \\
6\end{array}$ & 9.55 \\
\hline Males & $\begin{array}{r}27.6 \\
8 \\
\end{array}$ & $\begin{array}{r}6.0 \\
7 \\
\end{array}$ & $\begin{array}{r}28.7 \\
0 \\
\end{array}$ & $\begin{array}{r}6.7 \\
7 \\
\end{array}$ & $\begin{array}{r}28.2 \\
6 \\
\end{array}$ & $\begin{array}{r}6.4 \\
6 \\
\end{array}$ & 21.00 & $\begin{array}{r}4.7 \\
2 \\
\end{array}$ & $\begin{array}{r}27.3 \\
7 \\
\end{array}$ & 9.98 & $\begin{array}{r}24.6 \\
2 \\
\end{array}$ & 8.70 \\
\hline Females & $\begin{array}{r}28.4 \\
6\end{array}$ & $\begin{array}{r}7.3 \\
5\end{array}$ & $\begin{array}{r}30.3 \\
6\end{array}$ & $\begin{array}{r}7.0 \\
0\end{array}$ & $\begin{array}{r}29.4 \\
6\end{array}$ & $\begin{array}{r}7.2 \\
0\end{array}$ & 22.19 & $\begin{array}{r}5.1 \\
4\end{array}$ & $\begin{array}{r}29.9 \\
8 \\
\end{array}$ & $\begin{array}{r}12.2 \\
4\end{array}$ & $\begin{array}{r}26.2 \\
8\end{array}$ & $\begin{array}{r}10.2 \\
8\end{array}$ \\
\hline
\end{tabular}

Effects of program on children's social insecure behavior

To investigate whether there were differences on children's social insecure behavior between the two groups (i.e. experimental, control) before the intervention, a T-test 
for independent samples was applied; the findings showed that there were no significant pre-test differences between the groups, $T(192)=-1.857, p>.05$.

However, after the intervention, the results of ANOVA repeated measures with two factors (time $\mathrm{x}$ group) revealed that both the main effects of group $[F(1,192)=$ $\left.252.68, p<.001, \eta^{2}=.568\right]$ and time $\left[F(1,192)=21.87, p<.001, \eta^{2}=.10\right]$, as well as the interaction among these two factors $\left[F(1,192)=67.71, p<.001, \eta^{2}=.26\right]$ were all significant for a child's social insecure behavior. Moreover, as the results of T-test independent samples showed, children attending the intervention program scored significantly lower in social insecure behaviors than the control group, $T(192)=-$ $7.225, \mathrm{p}<.001$. This finding indicates that pre-school children could be supported in the educational framework on issues concerning their anxieties (separation anxiety, phobia, and general anxiety).

\section{Effects of program on children's aggressive behavior}

Before starting the intervention, results of T-test independent samples showed that all participants, regardless of group, did not differ in their aggressive behaviors, $T(192)=$ $-1.436, p>.05$.

After the intervention and in order to test the effect of group (one experimental, one control group) and time (pre- and post-test) on children's aggressive behaviors we applied one 2 × 2 repeated measures ANOVA; the findings revealed that both the main effects of group $\left[F(1,192)=15.69, p<.001, \eta^{2}=.08\right]$ and time $[F(1,192)=$ $\left.74.64, p<.001, \eta^{2}=.28\right]$ as well as the interaction between these two factors $[F(1,192)$ $\left.=43.49, p<.001, \eta^{2}=.18\right]$ were all significant for a child's aggressive behavior. Moreover, as the results of T-test independent samples showed, children attending the intervention program scored significantly lower in aggressive behaviors than the control group, $\mathrm{T}(192)=-5.457, \mathrm{p}<.001$. This means, in other words, that the effort to reduce - within the school framework - young children's aggression towards their classmates, teachers and/or their selves could be achieved through enhancing pupils' motor, sensual and creative abilities. 


\section{Discussion}

The present study was designed to examine the effectiveness of a physical education program in supporting pre-school students' social development. The strategies utilized were based on physical activities (that could be seen as sensual-motoric-games), and on kinetic theatrical playing.

The results of this study both support and extend existing knowledge about supporting children's social competence through physical education. Specifically, regarding the effect of the program on social insecure behavior, the findings suggest that both the physical activities as well as the kinetic theatrical playing affect positively students' socialization/social skills. These results are in accordance with other related studies, which indicated that physical education could improve a child's cooperative behavior, positive recognition, empathy, self-controlled, and social skills (Bailey et al., 2009; Mouratidou et al. 2007b; Peng, Wang, Huang, Shih, \& Chou, 2007; Pavlidou et al., 2012; Quay \& Peters, 2008; Tsangaridou et al., 2014), that sociodramatic play and rough-and-tumble play predict children's affective social competence (Lindsey \& Colwell, 2013) and that in the educational framework the interaction between peers, the educator, the instructional teaching methods, and the organizational dimensions promote pupils' social competencies (Bailey et al., 2009; Roeser, Eccles, \& Sameroff, 2000; Wentzel, 1991). Therefore, when in a kindergarten class students' expressiveness is supported - among others - through the body-language and when all students have the chance/opportunity to participate, enjoy, interact, and express their selves in physical activities - irrespective of their level of skills -, then their socialization is boosted. In turn, this means that pre-school educators should use extensively physical activities in the educational daily routine which are challenging, promote creativity, expression and interaction, in order to fulfil the educational goal concerning students' socialization.

Regarding children's aggressive behaviors, our findings suggest that it could be reduced, without requiring the daily activities taught in kindergarten be reconstructed: the game is the standard, usual practice of teaching at this educational level and in some cases, the participation and the joy of the playing are the main purposes of a daily lesson. So, it's no wonder, that doing physical activities (such as kinetic games and kinetic theatrical improvisations) "transforms" children's aggression into creative 
action and playing by rules and helps them to ease and deescalate; ultimately, several studies in the past have corroborated that physical education/activities (for example, team games) help one student to defuse negative emotions (such as anger, rage, etc.), and to cooperate and to respect her/his peers (Bailey_et al., 2009; Hastie \& Buchanan, 2000; Wang \& Sugiyama, 2014).

Moreover, as Pellegrini and Smith claimed (1998), a lack of opportunity to engage in physical activity play leads to compensation later, therefore play is of functional benefit. Apparently the constructive but also free "character" of activities such as kinetic games, the focus on participation itself and on self-expression through the body-language and the removal of comparison/competitive circumstances among students, serves as a framework for negative feeling alleviation and helps children to experience social acceptance, sharing and successes, which in turn strengthen one's ability to control her/him-self.

Although this study revealed important information about the subject matter of PE related to the preschool-children's socio-moral development, there were a number of limitations. First, the assessment of children's social skills was based on their preschool-educators ratings and may reflect teacher perceptions rather than actual children's behavior. Second, the preschoolers in control group although didn't attend PE lessons during the intervention program, they participated in group activities (such as pedagogical games, kids arts and crafts activities), which could promote children's interaction and therefore also their social relationships. Finally, in the absence of a follow-up study results of the study should be generalizing with caution.

In summary, through this study we attempted to establish a way of teaching in preschool children by aiming to foster their social abilities and to reduce their aggressive behaviors. It seems that in early childhood, the socio-moral development enhancement requires a systematic and careful planning of the physical activities taught in the educational framework and that an appropriate design of the lessons could promote kid's socio-moral development without deviating from the present curriculum. 


\section{References}

Altermatt, E. R. (2011). Capitalizing on academic success: Students' interactions with friends as predictors of school adjustment. Journal of Early Adolescence, 31(1), 174-203.

Bailey, R., Armour, K., Kirk, D., Jess, M., Pickup, I., Sandford, R., \& BERA Physical Education and Sport Pedagogy Special Interest Group (2009). The educational benefits claimed for physical education and school sport: an academic review. Research Papers in Education, 24(1), 1 - 27.

Boivin, M., Hymel, S., \& Bukowski, W. M. (1995). The roles of social withdrawal, peer rejection, and victimization by peers in predicting loneliness and depressed mood in childhood. Development and Psychopathology, 7(4), 765-785.

Brophy-Herb, H. E., Lee, R. E., Nievar, M. A., \& Stollak, G. (2007). Preschoolers' social competence: Relations to family characteristics, teacher behaviors and classroom climate. Journal of Applied Developmental Psychology, 28, 134-148.

Chen, Y. H., Arria, A. M., \& Anthony, J. C. (2003). Firesetting in adolescence and being aggressive, shy, and rejected by peers: New epidemiologic evidence from a national sample survey. Journal of the American Academy of Psychiatry and the Law, 31(1), 44-52.

Chen, X., Zappulla, C., Coco, A. L., Schneider, B., Kaspar, V., De Oliveira, A. M., He, Y., Li, D., Li, B., Bergeron, N., Tse, H. C., \& DeSouza, A. (2004). Selfperceptions of competence in Brazilian, Canadian, Chinese and Italian children: Relations with social and school adjustment. International Journal of Behavioral Development, 28(2), 129-138.

Chung-Hall, J., \& Chen, X. (2010). Aggressive and prosocial peer group functioning: Effects on children's social, school, and psychological adjustment. Social Development, 19(4), 659-680.

Citrome, L., \& Volanka, J. (2001). Aggression and violence in patients with schizophrenia. In M. Hawng, \& P. Bermanzohn (Eds.), Schizophrenia and 
comorbid conditions. Diagnosis and treatment (pp. 149- 185). Washington, DC: American Psychiatric Press Inc.

Crick, N. R., Casas, J. F., \& Mosher, M. (1997). Relational and Overt Aggression in Preschool. Developmental Psychology, 33(4), 579-588.

Denham, S. A. (2006). Social-emotional competence as support for school readiness: what is it and how do we assess it? Early Education and Development, 17(1), 57-89.

Dodge, K. A., Lansford, J. E., Burks, V. S., Bates, J. E., Pettit, G. S., Fontaine, R., \& Price, J. M. (2003). Peer rejection and social information-processing factors in the development of aggressive behavior problems in children. Child Development, 74(2), 374-393.

Erickson, M. F., Sroufe, L. A., \& Egeland, B. (1985). The relationship between quality of attachment and behavior problems in preschool in a high-risk sample. Monographs of the Society for Research in Child Development, 50 (1/2), 147166.

Gibbons, L. S., \& Ebbeck, V. (1997). The effect of different teaching strategies on the moral development of physical education students. Journal of Teaching in Physical Education, 17, 85-98.

Gibbons, L. S., Ebbeck, V., \& Weiss, M. R. (1995). Fair play for kids: Effects on the moral development of children in physical education. Research Quarterly for Exercise and Sport, 3, 247-255.

Greenberg, M. T., Weissberg, R. P., O'Brien, M. U., Zins, J. E., Fredericks, L., Resnik, H., \& Elias, M. J. (2003). Enhancing school-based prevention and youth development through coordinated social, emotional, and academic learning. American Psychologist, 58(6/7), 466-474.

Gregoriadis, A., Grammatikopoulos, V., \& Zachopoulou, E. (2013). Evaluating preschoolers' social skills: The impact of a physical education program from the 
parents' perspective. International Journal of Humanities and Social Science, 3(10), 40-51.

Harris, J. R. (1995). Where is the child's environment? A group socialization theory of development. Psychological Review, 102(3), 458-489.

Hastie, P.A., \& Buchanan, A.M. (2000). Teaching responsibility through sport education: prospects of a coalition. Research Quarterly for Exercise and Sport, 71(1), 25-35.

Helmsen, J., Koglin, U., \& Petermann, F. (2012). Emotion regulation and aggressive behavior in preschoolers: The mediating role of social information processing. Child Psychiatry \& Human Development, 43, 87-101.

Hernández, M., Eisenberg, N., Valiente, C., VanSchyndel, S. K., Spinrad, T. L., Silva, K. M., Berger, R. H., Diaz, A., Terrell, N., \& Thompson, M. S. (2016). Emotional expression in school context, social relationships, and academic adjustment in kindergarten. Emotion, 11, No pagination specified. http://dx.doi.org/10.1037/emo0000147

Hodges, E. V., \& Perr, D. G. (1999). Personal and interpersonal antecedents and consequences of victimization by peers. Journal of Personality and Social Psychology, 76(4), 677-685.

Howell, K. H., Miller, L. E., Lilly, M. M., \& Graham-Bermann, S. A. (2013). Fostering social competence in preschool children exposed to intimate partner violence: Evaluating the preschool kids' club intervention. Journal of Aggression, Maltreatment \& Trauma, 22, 425-445.

Howes, C. (1987). Social competence with peers in young children: Developmental Sequences. Developmental Review, 7, 252-272.

IPC-International Elementary Curriculum (2005). The Learning Goals. Retrieved from: http://www.greatlearning.com/ipc/the-ipc/ipc-learning-goals.

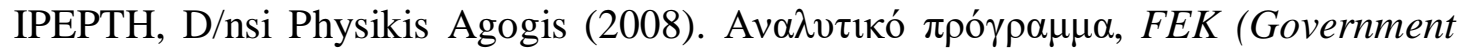
Legislation Journal), 304. 
Keane, S. P., \& Calkins, S. D. (2004). Predicting kindergarten peer social status from toddler and preschool problem behavior. Journal of Abnormal Child Psychology, 32(4), $409-423$.

Ladd, G. W., \& Burgess, K. B. (1999). Charting the relationship trajectories of aggressive, withdrawn, and aggressive/withdrawn children during early grade school. Child Development, 70( 4), 910-929.

Lindsey, E. W., \& Colwell, M. J. (2013). Pretend and physical play: Links to preschoolers' affective social competence. Merrill-Palmer Quarterly, 59(3), 330 $-360$.

Logan, S. W., Schreiber, M., Ragonesi, C. B., Pritchard, B., George, L., \& Galloway, J. C. (2014). Physical activity-socialization co-occurrence in typically developing toddlers. Research Quarterly for Exercise and Sport, 85(S1), A85.

McLaughlin, C. \& Byers, R. (2001). Personal and social development for all. London: David Fulton.

McClelland, M. M., Morrison, F. J. (2003). The emergence of learning-related social skills in preschool children. Early Childhood Research Quarterly, 18, 206-224.

McClelland, M. M., Morrison, F. J., \& Holmes, D. L. (2000). Children at risk for early academic problems: The role of learning-related social skills. Early Childhood Research Quarterly, 15(3), 307-329.

Miller, S. C., Bredemeier, J. L., \& Shields, L. L. (1997). Sociomoral education through physical education with at-risk children. Quest, 49(1), 114-129.

Mouratidou, K. (2010). Supporting students' moral development through physical education. In: R. V. Nata (Ed.) Progress in Education, Volume 18 (pp. 99-117). New York: Nova Science Publishers.

Mouratidou, K., Barkoukis, V., Zahariadis, P., \& Arampatzi, A. (2007a). Evaluation of students' social ability: Greek version of checklists for aggressive behaviour and social insecurity in elementary education. Social Psychology of Education, 10(4), 495-508. 
Mouratidou, K., Goutza, S., \& Chatzopoulos, D. (2007b). Physical education and moral development: An intervention program to promote moral reasoning through physical education in high school students. European Physical Education Review, 13(1), 41-56.

NASPE-National Association for Sport and Physical Education (2004). Moving into the Future - National Standards for Physical Education, $2^{\text {nd }}$ edition.

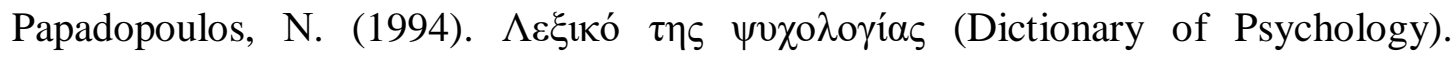
Athens.

Parker, J.G., \& Asher, S.R. (1987). Peer relations and later personal adjustment: Are low-accepted children at risk? Psychological Bulletin, 102, 357-389.

Pavlidou, E., Arvanitidou, V., \& Chatzigeorgiadou, S. (2012). The effectiveness of a pilot intervention program of physical education in multicultural preschool education. Journal of Educational Research, 1, 53-66.

Pellegrini, A. D., \& Smith, P. K. (1998). Physical activity play: The nature and function of a neglected aspect of play. Child Development, 69(3), 577-598.

Peng, H. C., Wang, W. Y., Huang, M. Y., Shih K. T., \& Chou, C. C. (2007). Effects of a movement education program on the problem solving and socialization skill of sixth-grade students in elementary physical education. Research Quarterly for Exercise and Sport, 78(1), A-69.

Peterman, F., \& Petermann, U. (2001). Training mit aggressiven Kindern (10 ${ }^{\text {te }}$ Aufl.) (Training with aggressive children). Weinheim: Beltz.

Peterman, U., \& Petermann, F. (2003). Training mit sozial unsicheren Kindern ( $8^{\text {te }}$ Aufl.) (Training with socially insecure children). Weinheim: Beltz.

Quay, J., \& Peters, J., (2008). Skills, strategies, sport, and social responsibility: Reconnecting physical education. Journal of Curriculum Studies, 40(5), 601626. 
Rimm-Kaufman, S. E., Pianta, R. C., \& Cox, M. J. (2000). Teachers' judgments of problems in the transition to kindergarten. Early Childhood Research Quarterly, 15(2), 147-166.

Roeser, R. W., Eccles, J. S., \& Sameroff, A. J. (2000). School as a context of early adolescents' academic and social-emotional development: A summary of research findings. The Elementary School Journal, 100(5), 443-471.

Rose-Krasnor, L. (1997). The nature of social competence: A theoretical review. Social Development, 6(1), 111-135.

Rosenberg, C. (1990). Praxis fuer das Bewegungstheater (Practice for the Bodytheater). Aachen: Meyer \& Meyer.

Roseth, C. J., Pellegrini, A. D., Bohn, C. M., Van Ryzin, M., \& Vance, N. (2007). Preschoolers' aggression, affiliation, and social dominance relationships: An observational, longitudinal study. Journal of School Psychology, 45, 479-497.

Rossem, R. V.,Vermande, M.,Völker, B., \& Baerveldt, C. (2015). Social capital in the classroom: a study of in-class social capital and school adjustment. British Journal of Sociology of Education, 36(5), 669-688.

Rubin, K. H., Bukowski, W. M., \& Parker, J. G. (2006). Peer interactions, relationships, and groups. In W. Damon, R. M. Lerner (Series Eds.), \& N. Eisenberg (Vol. Eds.), The handbook of child psychology: Vol 3. Social, emotional, and personality development ( $6^{\text {th }}$ ed., pp. 571-645). New York, NY: Wiley.

Sandstrom, M. J., Cillessen, A. H., \& Eisenhower, A. (2003). Children's appraisal of peer rejection experiences: Impact on social and emotional adjustment. Social Development, 12(4), 530-550.

Schmolke, A. (1976). Das Bewegungstheater (Body-theater). Wolfenbuettel \& Zuerich: Moeseler.

Schwab-Stone, M., Chen, C., Greenberger, E., Silver, D., Lichtman, J., \& Voyce, C. (1999). No Safe Haven II: The effects of violence exposure on urban youth. 
Journal of the American Academy of Child and Adolescent Psychiatry, 38(4), 359-367.

Sebanc, A.M. (2003). The friendship features of preschool children: Links with prosocial behavior and aggression. Social Development, 12(2), 249-268.

Serpell, Z. N., \& Mashburn, A. J. (2012). Family-school connectedness and children's early social development. Social Development, 21(1), 21-46.

Stan, M. M. (2013). Social and emotional competence-predictors of school adjustment. Procedia - Social and Behavioral Sciences, 76, 29-33.

Ştefan, C. A., \& Miclea, M. (2013). Effects of a multifocused prevention program on preschool children's competencies and behavior problems. Psychology in the Schools, 50(4), 382-402.

Telama, R. (1999) Moral development. In Y. V. V. Auweele, F. Bakker, S. Biddle, M. Durand, \& R. Seiler (Eds.), Psychology for physical educators (pp. 321-342). Champaign, IL: Human Kinetics.

Tsangaridou, N., Zachopoulou, E., Liukkonen, J., Grasten, A., \& Kokkonen, M. (2014). Developing preschoolers' social skills through cross-cultural physical education intervention. Early Child Development and Care, 184(11), 15501565 .

Turner P. J. (1991). Relations between attachment, gender, and behavior with peers in preschool. Child Development, 62, 1475-1488.

Wang, X., \& Sugiyama, Y (2014). Enhancing Social Skills Through College Physical Education. Journal of Physical Education and Sport, 14(2), 158-163.

Wentzel, K.R. (1991). Social Competence at School: Relation Between Social Responsibility and Academic Achievement. Review of Educational Research, 61(1), 1-24.

Wichmann, C., Coplan, R. J., \& Daniels, T. (2004). The social cognitions of sociallly withdrawn children. Social Development, 13(3), 377-392. 
Yeates, K. O., \& Selman, R. L. (1989). Social competence in the schools: Toward an integrative developmental model for intervention. Developmental Review, 9, 64100.

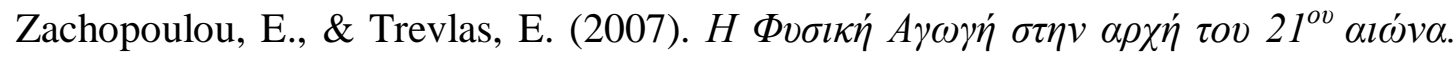
$\Sigma \kappa o \pi o i-\sum \tau o ́ \chi o l-E \pi l \delta \imath \omega^{\prime} \xi \varepsilon l \varsigma$ (The Physical Education at the beginning of the $21^{\text {st }}$

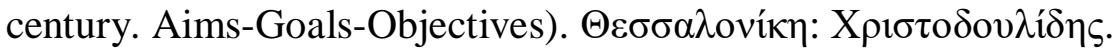

Zhang, G., Zhao, S., Liang, Z., Li, D., Chen, H., \& Chen, X. (2015). Social interactions with familiar and unfamiliar peers in Chinese children: Relations with social, school, and psychological adjustment. International Perspectives in Psychology: Research, Practice, Consultation, 4(4), 239-253.

Zupančiča, M.,\& Kavčiča, T. (2011). Factors of social adjustment to school: child's personality, family and pre-school. Early Child Development and Care, 181(4), 493-504. 